\title{
AKTIVITAS PERDAGANGAN DI KERESIDENAN JEPARA 1843-1891
}

\author{
Alamsyah \\ Jurusan Sejarah, Fakultas Ilmu Budaya, Universitas Diponegoro, Semarang \\ alam_mahir@yahoo.com
}

\begin{abstract}
When the role of Jepara as a trading city deteriorated from the beginning $19^{\text {th }}$ century, the life of Jepara Residency community shifted from maritime sector with a trading base to agrarian sector. The shift to agrarian sector which based on agriculture and plantation, and supported by the sea outputs made this residency attractive for traders. Both local traders, neighboring traders around Jepara, foreign eastern traders and interinsuler, as well as European traders. The traded products were exported to the surrounding areas of the residency, outer islands of Java, Singapore, and Europe. The export activities were carried out to other places through Semarang and Surabaya ports. In addition, the import activities also took place because this residency was a potential section in marketing imported products. It shows that in 19 $19^{\text {th }}$ century, especially around 1843 to 1891 the trading activities in Jepara Residency was still in existence.
\end{abstract}

Keywords : Activity, Trading, Residency, Jepara Residency, Export, Import

\section{ABSTRAK}

Meredupnya Jepara sebagai kota dagang sejak awal abad ke-19 membuat kehidupan masyarakat Keresidenan Jepara beralih dari sektor maritim yang berbasis perdagangan ke sektor agraris. Beralihnya ke sektor agraris yang berbasis pada pertanian, perkebunan, dan ditopang oleh hasil laut justru membuat Keresidenan ini mempunyai daya tarik bagi pedagang. Baik pedagang lokal, pedagang sekitar wilayah Jepara, pedagang Timur Asing dan interinsuler, maupun pedagang Eropa. Produk yang diperdagangkan diekspor ke wilayah sekitar Keresidenan, interinsuler, Singapura, dan Eropa. Kegiatan ekspor ke interinsuler dan ke luar negeri dilakukan melalui pelabuhan Semarang dan Surabaya. Selain itu, kegiatan impor juga berlangsung karena keresidenan ini merupakan pangsa potensial dalam memasarkan produk impor. Ini menunjukkan bahwa pada abad ke-19, terutama sekitar tahun 1843 hingga 1891 aktivitas perdagangan di keresidenan Jepara masih tetap eksis.

Keywords : Aktivitas, perdagangan, Keresidenan Jepara, ekspor, impor
PENDAHULUAN

Pada abad ke-16 sampai dengan abad ke-18 Jepara masih bisa menampilkan diri sebagai kota dagang yang didukung oleh aktivitas agraris di pedalaman (Lekkerkerker, 1932: 27; de Graaf \& Pigeaud, 1985: 124-125). Akan tetapi, sejak kekuasaan VOC digantikan oleh Hindia Belanda di awal abad ke-19 dan dominasi pemerintah kolonial yang semakin mendalam, peranan Jepara sebagai kota dagang diduga mengalami kemunduran.
Ada kesan pada abad-abad selanjutnya volume perdagangan di Keresidenan ini telah redup. Aktivitas ekonomi yang dominan adalah ekonomi berbasis agraris. Penilaian tersebut adalah wajar karena pada abad ke-19 kolonialisme di Jawa termasuk di Keresidenan Jepara semakin intensif. Pada masa ini diperkenalkan apa yang disebut cultuurstelsel (tanaman paksa) dan sejak tahun 1870 juga diperkenalkan politik liberal yang memberi hak bagi pihak swasta Belanda mengadakan eksploitasi besar-besaran. Pada akhir abad ke-19 
juga dipandang sebagai periode apa yang disebut mindere welvaart, kemerosotan kemakmuran alias kesengsaraan dan penderitaan ekonomis (Furnivall. 2009: 145-151; Geertz. 1983: 56; Fasseur. 1975: 286). Meskipun demikian pada $\mathrm{m}$ as a $\mathrm{S}$ istem Tan $\mathrm{T}$ Paks a (cultuurstelsel) ada hal-hal yang bersifat positif di Keresidenan Jepara (Van Niel. 2003: 34-70; Elson. 1994: 323-324) yaitu masih eksisnya perdagangan lokal, interinsuler, dan internasional meskipun dalam skala kecil.

Salah satu penyebab bertahannya aktivitas perdagangan di Jepara adalah adanya perpaduan potensi ekonomi hinterland dan ekonomi kota. Kota-kota yang terdapat di pusat-pusat ibukota kabupaten dan beberapa distrik di Keresidenan Jepara lebih condong menunjukkan aktivitas perdagangan, kegiatan pasar, industri, dan kerajinan. Di kota inilah terdapat kegiatan penjualan, ekspor, dan kegiatan perdagangan. Jepara masih menjadi pusat pertukaran komoditas (barang dagangan) yang masuk maupun keluar antara hinterland dan forelands (antara pedalaman dengan bagian depan) (Murphey, 1989: 231).

Oleh karena itu, tulisan ini ingin menunjukkan bahwa pada abad ke-19, di tengah penetrasi ekonomi kolonial yang semakin intensif, masyarakat Keresidenan Jepara mempunyai kemampuan melakukan adaptasi terhadap perubahan ekonomi yang ditandai dengan eksisnya aktivitas perdagangan.

\section{METODE PENELITIAN}

Rekonstruksi peristiwa sejarah ekonomi ini menggunakan metode sejarah yang terdiri atas heuristik, kritik, interpretasi, dan historiografi (Garraghan, 1946: 34; Gottschalk, 1986: 32). Heuristik adalah tahapan atau kegiatan menemukan dan menghimpun sumber, informasi, dan jejak masa lalu (Garraghan, 1946: 34; Gottschalk, 1986: 32; Herlina, 2008: 15). Heuristik yang dilakukan mendasarkan pada sumber primer dan sumber sekunder (Herlina, 2008: 17-24). Sumber primer diperoleh dari hasil penelitian di Arsip Nasional Republik Indonesia dan di Arsip Nasional Kerajaan Belanda atau ARA (Algemeen Rijksarchief) yang berada di Den Haag. Tahapan kedua adalah melakukan kritik terhadap sumbersumber yang telah diperoleh. Kritik ini ditujukan terhadap keabsahan sumber baik yang berkaitan dengan otentisitas sumber maupun kredibilitas sumber (Herlina, 2008: 24).

Setelah sumber ditemukan dan dikritik maka proses selanjutnya adalah melakukan interpretasi terhadap berbagai fakta sejarah yang telah terkumpul. Pada tahapan ini sejarawan harus jujur mengatakan dari mana data itu diperoleh baik melalui interpretasi analisis maupun interpretasi sintesis (Garraghan, 1946: 321; Herlina, 2009: 40). Tahapan terakhir adalah historiografi yaitu melakukan proses penulisan dalam rangka merekonstruksi peristiwa sejarah ekonomi di Jepara (Herlina, 2009: 56).

\section{HASIL DAN PEMBAHASAN}

\section{Pedagang Timur Asing dan Interinsuler}

Aktivitas perdagangan di Jepara pada tahun 1840-an hingga 1850-an sebagian besar dikuasai oleh pedagang Timur Asing. Selain pedagang Cina, ada juga pedagang Arab dan Moor yang melakukan aktivitas perdagangan di Jepara. Mereka datang dari Semarang dan Surabaya untuk menjual berbagai barang dagangan, terutama kain Eropa dan kain tradisional. Barang-barang 
yang diperdagangkan ada yang berasal dari Eropa dan ada yang berasal dari Jawa seperti besi dan tembikar, makanan, gambir, tembakau, lilin, cat dan kayu. Barang yang diekspor adalah kopi, gula, kayu manis, padi, beras, coklat, gula putih dan merah, kapas, kapok, buah pinang, minyak jarak, rokok, minyak kacang dan minyak kelapa, terasi, sirup, tembikar, batu lantai dan berlapis semen, genting, kapur, perabotan dan potongan kayu kecil (A.V. 1843, bundel Jepara no. 4.1 ANRI; A.V. 1850, bundel no. 4.II.a. ANRI). Adapun barang yang diimpor antara lain besi, tembaga, kuningan, timah, porselin, tembikar, barang-barang kaca, tembakau, gambir, lilin, bahan katun polos dan cap, dan cita (A.V. 1850, bundel no. 4.II.a. ANRI).

Pada tahun 1857 seorang Letnan Cina di Juana sekaligus sebagai seorang pengusaha juga mengelola perdagangan (A.V. 1850, bundel no. 4.II.a. ANRI; Politiek Verslag der Residentie Japara over het Jaar 1857 Bundel Jepara No. 5.II A). Perdagangan di keresidenan ini sebagian besar dikuasai oleh para opsir Cina yang berlokasi di Semarang. Pada tahun ini kebanyakan orang Cina melakukan perdagangan domestik dan mereka tidak ada yang memiliki perkebunan (P.V. 1857, bundel Jepara No. 5.II A).

Selama tahun 1858 panen tebu, padi, tanaman kedua, dan tanaman yang lainnya berlimpah sehingga mendorong perdagangan ekspor. Perdagangan ekspor ini dikelola oleh pedagang Cina dan pedagang orang lokal (pribumi). Pedagang Cina menguasai perdagangan besar. Perdagangan ekspor yang dilakukan oleh pedagang Cina antara lain padi, beras, nila tradisional, gula tebu, buah-buahan, barangbarang peti dan perabotan, kapas, ikan kering dan asin, telur, ampas minyak, dan buncis. Barang-barang tersebut dikirim dari Keresidenan Jepara ke Sin- gapura. Barang-barang Ekspor dari Jepara juga dikirim ke Madura dan Borneo (A.V. 1858, bundel no. 5. II.D).

Hasil komoditas Jepara juga diekspor ke Keresidenan Rembang, pulau Madura, dan Demak. Daerah-daerah ini memerlukan komoditas dari Jepara. Namun bila daerah tersebut produksinya berlimpah, seperti Kabupaten Demak, maka pada tahun tertentu tidak mengambil komoditas dari Jepara. Barang-barang yang diekspor dari Jepara ke beberapa daerah antara lain padi, ikan kering dan ikan asin (A.V. 1858, bundel no. 5. II.D).

Selain kegiatan ekspor, pada tahun 1858 keresidenan ini juga mengimpor barang melalui Semarang dan Surabaya (A.V. 1858, bundel no. 5. II.D). Komoditas perdagangan yang diimpor ke Jepara antara lain kain, gambir, tembakau, barang-barang tembaga, tembikar Eropa dan Cina, barangbarang kaca, lilin, minyak, timah, timah hitam, kapas kasar, barang besi, dan ro$\tan$ (A.V. 1858, bundel no. 5. II.D).

Pada tahun 1859, padi menjadi komoditas ekspor yang penting bagi Jepara. Selain padi, produk tanaman kedua juga memberikan banyak aktivitas bagi masyarakat. Pada periode ini selain pribumi, pedagang Cina juga masih menguasai perdagangan besar. Perdagangan utama dalam skala besar terjadi dengan Semarang dan Surabaya. Melalui 2 (dua) daerah ini, produk Jepara diekspor ke luar Jawa. Produk dari Jepara juga diekspor ke Madura, Bali, Bawean, Borneo, Banjarmasin, dan Belitung. Adapun Keresidenan Rembang, Afdeeling Demak, dan Grobogan mengekspor produk dari Jepara sebatas pada produk yang digunakan untuk memenuhi kebutuhan hidup sehari-hari. Ramainya perdagangan ini bermanfaat bagi peningkatan kemakmuran masyarakat (A.V. 1859, bundel 5.II.F).

Meskipun panen padi di Jepara 
pada tahun 1860 tidak menguntungkan, tetapi ekspor tetap tinggi terutama produk tanaman kedua. Para pedagang besar Cina melakukan aktivitas perdagangan dengan baik. Perdagangan lewat laut dikelola melalui Semarang dan Surabaya. Melalui tempat tersebut barang diekspor ke Madiun, Bawean, Belitung, Borneo, dan Bali. Selain melalui laut, perdagangan juga dilakukan melalui transportasi darat. Perdagangan produk melalui transportasi darat dilakukan dari Jepara ke Rembang, Demak, Grobogan, Surakarta, dan Semarang. Pada masa ini produk yang diperdagangkan meliputi minyak, nila dan ampasnya, buncis hitam, kapur, gula, kapas, dan ikan. Selain itu masyarakat Jepara juga mengembangkan sektor perikanan, pertanian, usaha industri, dan pengangkutan dalam rangka mendukung aktivitas perdagangan (A.V. 1860).

Pada tahun 1861, pedagang Cina mengimpor barang dari Eropa ke Jepara. Selain mendatangkan barang dari Eropa, mereka juga mendatangkan barang dari kepulauan Timur serta dari seluruh Jawa. Selain mengimpor barang, pedagang Cina juga membeli produk tanaman kedua seperti kapas, berbagai jenis kacang, berbagai bahan pangan dari orang pribumi, mengelola pemerasan minyak, dan membeli benih nila (A.V. 1861, bundel Jepara 6.1.C). Tentu produk lokal Jepara yang dibeli orang Cina biasanya diekspor ke beberapa daerah baik lokal, antar daerah, maupun interinsuler.

Pada tahun 1862 dan 1863 hasil panen padi di keresidenan ini tidak begitu menguntungkan. Perdagangan beras yang dilakukan orang Cina di keresidenan ini tidak begitu penting karena produksi beras sedikit. Barang yang diperdagangkan jenisnya sama dengan periode sebelumnya. Namun demikian ekspor masih tetap berjalan dalam ben- tuk produk hasil tanaman kedua. Kegiatan ekspor ini memberikan keuntungan besar bagi pedagang Cina. Pada periode ini perdagangan lewat laut melalui Semarang dan Surabaya. Sementara itu perdagangan ke Madura, Bawean, Belitung, Borneo dan Bali juga tetap berjalan. Perdagangan lewat darat dilakukan dengan Rembang, Demak, Grobogan, Surabaya dan Semarang (A.V. 1862, bundel no. 6.1. F). Dampak positif dari dinamisnya perdagangan ini membuat uang yang beredar di wilayah ini cukup banyak (A.V. 1862, bundel no. 6.1. F).

Para pemborong Cina dan anak buahnya membeli hasil bumi dari orang -orang pribumi. Biasanya mereka terlebih dahulu memberi uang muka dalam jumlah sedikit. Tetapi karena persaingan sangat ketat, hal ini tidak merugikan penduduk pribumi. Kadangkala ada asumsi bahwa dengan uang muka yang kecil, maka orang pribumi akan menjadi korban dalam setiap transaksi perdagangan karena kelicikan dan kepandaian orang Cina. Tetapi kenyataan menunjukkan bahwa justru yang terjadi sebaliknya. Uang muka yang telah diberikan menjadi hilang bila orang Cina tidak mematuhi kesepakatan lisan yang telah dibuat dengan penduduk pribumi. Pada kondisi ini justru pembeli Cina inilah kadangkala menjadi korban penipuan karena tidak ada kontrak yang dibuat dengan orang penduduk pribumi. Tetapi kasus seperti ini sangat jarang terjadi (P.V. 1863 Bundel No. 6. I. G).

Pada tahun 1876, perdagangan kain mengalami peningkatan karena pedagang Cina selain menjual di toko juga menjajakan secara keliling. Jenisjenis kain yang paling disukai adalah kain katun putih polos, jenis keper, dan jenis madapolam terutama yang digunakan untuk membatik. Jenis cita dan kain cap-capan buatan Eropa juga 
sangat disukai, terutama untuk baju dan kebaya. Harga kain buatan Belanda dan Jerman yang murah dan daya tahannya yang lama lebih disukai daripada kain buatan Inggris dan Prancis. Pada tahun ini produk yang diekspor adalah perabotan Jepara, batubata, ubin, dan genting (A.V. 1876, bundel No. 7.II.C; A.V. 1877, bundel No. 7.II.D).

Pada tahun 1870-an pedagang Cina mengimpor produk yang berasal dari Eropa, Cina, Kepulauan Timur, dan Jawa. Produk yang diimpor kemudian dijual di Jepara. Selain menjual barang impor, pedagang Cina ini juga membeli beras, kapas, berbagai jenis kacang, bungkil, rempah-rempah, padi, nila melakukan perdagangan gambir, kain, kain, padi, beras, minyak, kacang, bungkil, minuman keras, alat-alat rumah tangga dan kebutuhan rakyat sehari-hari dari Jepara (A.V. 1870, bundel No. 7.I.A; A.V. 1871, bundel No. 7.I.C; A.V. 1872, bundel No. 7.1.E; A.V. 1873, bundel No. 7.I.G; A.V. 1874, bundel No. 7.II.A; A.V. 1876, bundel No. 7.II.C; A.V. 1879, bundel No. 7.II.,F; A.V. 1880, bundel No. 7.II.G; A.V. 1881, bundel No. 7.II.G). Pada periode, ini pedagang Cina juga masih membuka toko-toko kecil. Mereka menjual makanan, minuman, kain, barang-barang besi, cat warna, dan peralatan lain buatan Eropa (P.V. 1870, bundel No. 7.I.B; A.V. 1871, bundel No. 7.I.C).

Pada tahun 1877 jumlah padi dan beras dari Jepara yang dijual ke Keresidenan Rembang lebih banyak daripada tahun sebelumnya. Beras Jepara ini juga dijual ke Blora, Demak, dan Semarang. Beras tersebut sebagian besar digunakan untuk konsumsi lokal. Pada tahun 1878, ekspor beras ke Rembang dan sebagian Karesidenan Surabaya meningkat pesat karena di daerah tersebut terjadi kelangkaan bahan pangan (A.V. 1877, bundel No. 7.II.D; A.V.1875, bundel No. 7.II.B; A.V. 1878, bundel Jepara, No. 7.II.E).

Perdagangan di pedalaman dil- akukan oleh pedagang Cina. Pada tahun 1887 mereka membeli produk seperti ketela, ubi, dan komoditas lain. Produk ini kemudian dikirim ke ibukota keresidenan (A.V. 1887, bundel No. 7.II.M). Produk yang mempunyai nilai jual adalah bungkil, meskipun harganya cukup rendah. Bungkil ini dijual ke pabrik, ke wilayah lain, dan ada yang diekspor ke Cina. Bungkil digunakan untuk pupuk tanah pertanian.

Pada tahun 1880-an, perdagangan kain hampir seluruhnya dikuasai oleh orang Cina dan orang Bawean. Mereka menjajakan barang dagangan dengan cara berkeliling. Di Afdeeling Juana perdagangan kain meningkat karena adanya pertambahan jumlah toko. Seperti tahun 1870 -an, pada periode 1880 -an pedagang Cina selain membuka toko juga menjajakan barang dagangannya dengan cara berkeliling. Pada masa ini perdagangan beras di Welahan yang dilakukan oleh orang-orang Cina sangat ramai (A.V. 1882, bundel No. 7.II.H).

Produk perdagangan lain yang dijual pada tahun 1880-an, adalah kapuk. Produksi kapok di keresidenan ini sangat tinggi dan diekspor ke Eropa melalui Semarang. Benih kapuk juga di ekspor ke Eropa untuk memenuhi permintaan pabrik minyak (A.V. 1887, bundel No. 7.II.M). Kapuk merupakan komoditi penting di Afdeeling Pati dan Juana. Pada tahun 1889, produk kapok dari Pati sebanyak 200 ribu kilogram. Kapok ini dikirim ke Semarang kemudian diekpor ke Eropa. Perdagangan komoditas lain seperti pada tahun-tahun sebelumnya sangat ramai. Perdagangan domestik sangat penting dan lebih lebih ramai daripada tahun sebelumnya (A.V. 1889, bundel No. 7.II.O; A.V. 1889, bundel No. 7.II.O; A.V. 1887, bundel No. 7.II.M).

Pada tahun 1890-an hasil perdagangan lebih menguntungkan daripada tahun sebelumnya. Meskipun beras langka, perdagangan tanaman 
kedua seperti ketela sangat ramai. Produksi ketela dalam jumlah besar diangkut dari distrik di Muria ke tempat lain. Perdagangan kapok dari Afdeeling Pati dan Juwana serta perdagangan kopra dari Pati dan Jepara semakin meningkat. Selama tahun 1891 kopra sebanyak 5.400 kilogram dan 312.000 kilogram kapok diangkut dari Pati ke Semarang. Namun demikian untuk jenis kapok randu selama tahun 1891 hasilnya masih kurang menguntungkan karena panjangnya musim kemaraug (A.V. 1891, bundel No. 7.II.Q). Di Juana, perdagangan minyak bumi sangat ramai. Perdagangan ini dikuasai oleh kongsi Lasem. Pada tahun 1891 sebanyak 1.241.000 liter minyak diangkut (A.V. 1891, bundel No. 7.II.Q).

Selain pedagang Cina, di Jepara juga terdapat pedagang yang berasal dari luar pulau (interinsuler). Para pedagang ini berasal dari Makasar, Bugis, Bali, Borneo, Keling, Palembang, Sumatra dari pantai barat, Melayu dan Bengala. Jumlah mereka di Jepara semakin berkurang. Adapun pedagang yang dari Melayu terlibat dalam perdagangan penyelundupan. Selain orang-orang Bengala dan Bali, orang yang berasal dari interinsuler ini tinggal di kota-kota pelabuhan. Mereka kebanyakan menjadi pedagang dan pelaut (P.V. 1858, bundel No. 5.II.C; P.V. 1860, bundel No. 6.I.B).

Selain pedagang interinsuler, pada tahun 1860-an orang Arab juga mengelola perdagangan di Keresidenan Jepara. Produk yang diperdagangkan antara lain kain, bahan katun, makanan, beras, penjualan kuda, perdagangan kain, katun, hasil kerajinan tukang barangbarang emas, perak, dan batu mulia. Orang Timur Asing ini juga mengelola kegiatan pelayaran terutama menjadi pelaut (A.V. 1863, bundel Jepara No. 6.I.G; A.V. 1860).

Pada tahun 1860-an hingga 1880an penduduk Timur Asing melakukan perdagangan kecil dan menjadi pelaut. Orang Arab melakukan perdagangan kain, bahan katun, hasil bumi, beras, kuda, perhiasan emas, perak, serta batu permata. Mereka juga melakukan aktivitas perdagangan kain dan barangbarang rumah tangga. Orang Timur Asing lainnya melakukan perdagangan kecil dan menjadi pelaut. Aktivitas mereka lebih banyak membatasi diri pada perdagangan ibukota kabupaten (A.V. 1871, bundel No. 7.I.C; P.V. 1863, bundel No. 6. I. G; A.V. 1869, bundel No. 6.II. K; P.V. 1870, bundel No. 7.I.B; A.V. 1871, bundel No. 7.I.C; A.V. 1870, A.V. 1878, bundel Jepara, No. 7.II.E bundel No. 7.I.A; A.V. 1879, bundel No. 7.II.,F; A.V. 1880, bundel No. 7.II.G; A.V. 1881, bundel No. 7.II.G; P.V. 1857, bundel Jepara No. 5.II A; A.V. 1872, bundel No. 7.1.E; A.V. 1875, bundel No. 7.II.B; A.V. 1873, bundel No. 7.I.G; A.V. 1876, bundel No. 7.II.C; A.V. 1877, bundel No. 7.II.D).

\section{Pedagang Lokal}

Selain pedagang Timur Asing dan pedagang interinsuler, aktivitas perdagangan juga dilakukan oleh penduduk lokal. Posisi pedagang lokal ini hampir sama dengan pedagang $\mathrm{Ti}$ mur Asing (Cina, Arab, dan lainnya) dan pedagang interinsuler (Makasar, Bugis, Bali, Borneo, Keling, Palembang, Sumatra dari pantai barat, Melayu dan Bengala). Pedagang lokal menjual berbagai barang dagangan yang dihasilkan di Keresidenan Jepara. Kadangkala jenis produk pedagang lokal yang dijual sama dengan pedagang Timur Asing, namun volumenya kecil. Kebanyakan pedagang lokal menjual barang dagangannya di Keresidenan Jepara, Demak, Rembang, dan Blora.

Pedagang lokal ini menjual kain, produk pertanian, tembakau, dan ternak antar regenstchap di keresidenan ini. Mereka menjual barang dagangannya di 
Kudus dan di Pati. Para pedagang lokal juga menjadi pedagang perantara antara produsen dan konsumen. Kondisi ini berbeda dengan di daerah lain di Jawa. Bila di sebagian besar Jawa, perdagangan tangan kedua dan tangan ketiga biasanya dikuasai oleh orangorang Cina dan Arab. Di Keresidenan Jepara, perdagangan tangan kedua banyak yang dikelola oleh orang lokal. Para pedagang lokal mengunjungi ibukota dan kota-kota pedalaman di Jawa. Kadang-kadang para pedagang dari Jepara ini melakukan aktivitas perdagangan di daerah lain dalam waktu 1 hingga 2 tahun. Mereka berusaha mengumpulkan modal untuk keluarganya, termasuk mengumpulkan modal untuk membuat rumah kayu yang ditutup dengan genting dan dihiasi dengan ukiran (Van der Lith, 1896: 99).

Pedagang lokal mengelola kegiatan perdagangan sehingga perdagangan di Keresidenan Jepara cukup ramai. Para pedagang lokal juga menggunakan transportasi darat, pelabuhan, dan sungai. Pada tahun 1880 -an, perahu-perahu berukuran sedang masih dapat melewati kota. Selain perahu sedang, juga terdapat perahuperahu pribumi kecil yang mondarmandir di pasar besar yang terletak di aliran kanan sungai di Jepara (Veth, 1882: 765). Meskipun ekspor-impor tidak tinggi, banyak padi dari keresidenan Jepara diekspor ke Demak dan kadangkala padi dari Demak diimpor ke Jepara. Kegiatan impor ini tidak pernah diawasi ketika diangkut melalui jalur darat (A.V. 1843, bundel Jepara no. 4.1 ANRI).

Pedagang lokal menjual barang dagangan hasil buatannya sendiri di sepanjang jalan raya atau di pasar umum, dan di alun-alun (A.V. 1850, bundel no. 4.II.a. ANRI). Peranan pedagang lokal sangat penting. Mereka bergerak dari Kudus ke Barat serta dari
Jepara dan Juana melalui laut menuju ke Semarang. Dari Juana, pedagang lokal juga menuju ke sebelah timur Surabaya dan Madura untuk melakukan perdagangan dalam skala kecil (P.V. 1857). Di keresidenan ini, pedagang lokal banyak yang berasal dari Kudus. Di keresidenan ini, termasuk orang Kudus memiliki semangat usaha yang besar, sehingga tidak kalah jiwa usahanya bila dibandingkan dengan pedagang Cina. Di Kudus terdapat beberapa pedagang lokal yang kaya. Mereka mempunyai modal yang cukup besar dalam melakukan aktivitas perdagangan (P.V. 1857).

Di Kabupaten Pati dan Juana, produk beras banyak yang diekspor ke berbagai daerah. Di Kudus penduduk mampu menghasilkan produk tanaman kedua terutama gula merah, nila, dan kapas. Produksi tanaman kedua jumlahnya cukup besar karena ditunjang oleh kesuburan tanah (P.V. 1857).

Selama tahun 1858, produk tanaman tebu, padi, tanaman kedua, dan tanaman yang lainnya berlimpah sehingga mendorong perdagangan ekspor. Perdagangan ini selain dikelola oleh orang Cina, penduduk lokal juga memainkan peranan penting. Pedagang lokal kadangkala mampu bersaing dengan pedagang Cina. Pedagang lokal juga berperan dalam kegiatan ekspor produk nila, gula tebu, buah-buahan, barang-barang peti dan perabotan, kapas, ikan kering dan asin, telur, ampas minyak, dan buncis yang dikirim ke Singapura. Minimal posisi pedagang lokal sebagai perantara dengan pedagang Cina (A.V. 1858, bundel no. 5. II.D).

Pada tahun 1859, kegiatan ekspor produk padi dan tanaman kedua juga dilakukan oleh pedagang lokal. Mereka bersama dengan pedagang Cina menguasai menguasai perdagangan besar. 
Perdagangan skala besar dilakukan dengan Semarang, Surabaya, dan daerah di luar Jawa. Termasuk keterlibatan pedagang lokal dalam aktivitas perdagangan dengan Madura, Bali, Bawean, Borneo, dan Belitung. Keresidenan Rembang, Afdeeling Demak, Grobogan. Aktivitas perdagangan tersebut memajukan kemakmuran masyarakat lokal (A.V. 1859, bundel 5.II.F). Rute perdagangan yang dilakukan oleh pedagang Timur Asing, pedagang interinsuler, pedagang lokal, dan pedagang Eropa terlihat pada gambar di bawah.

Di ibukota kabupaten dijumpai pedagang lokal baik yang melakukan aktivitas melalui tranportasi darat maupun laut. Para pedagang darat banyak dijumpai di Kudus. Pedagang lokal ini juga terdapat di regentschap Juana. Mereka menjual bibit tebu di pasar dan menjual tebu untuk diolah menjadi gula. Perdagangan pribumi pada periode ini dilakukan dalam skala kecil (A.V. 1871, bundel No. 7.I.C; A.V. 1871, bundel No. 7.I.C; A.V. 1869, bundel No. 6.II. K; A.V. 1871, bundel No. 7.I.C).

Pedagang lokal juga terlibat da- lam perdagangan kain. Mereka menjual barang dagangannya dengan cara berkeliling. Jenis-jenis kain yang dijual adalah katun putih polos dan jenis madapolam terutama yang digunakan untuk membatik. Berkat peran pedagang lokal inilah maka perdagangan kain meningkat pesat di keresidenan ini (A.V. 1876, bundel No. 7.II.C; A.V. 1877, bundel No. 7.II.D).

Produk yang dipasarkan oleh pedagang lokal di pasar tradisional antara lain kacang, jarak, nila, cabai, kedelai, kapas, krai, ketimun, dan sebagainya. Perdagangan lokal ini tetap hidup dan menunjukkan salah satu faktor kemakmuran penduduk. Selain padi sebagai bahan pangan, terdapat pula tanaman jagung, ketela dan ubi yang jumlahnya sangat banyak. Sebagian besar tanaman tersebut diangkut ke Rembang dan Demak. Khusus di Jepara dan Juwana selain produk di atas juga diperdagangkan ikan laut dan ikan dari kolam (A.V. 1875, bundel No. 7.II.B; A.V. 1874, bundel No. 7.II.A).

Perdagangan di pedalaman selain dilakukan oleh orang Cina juga dil-

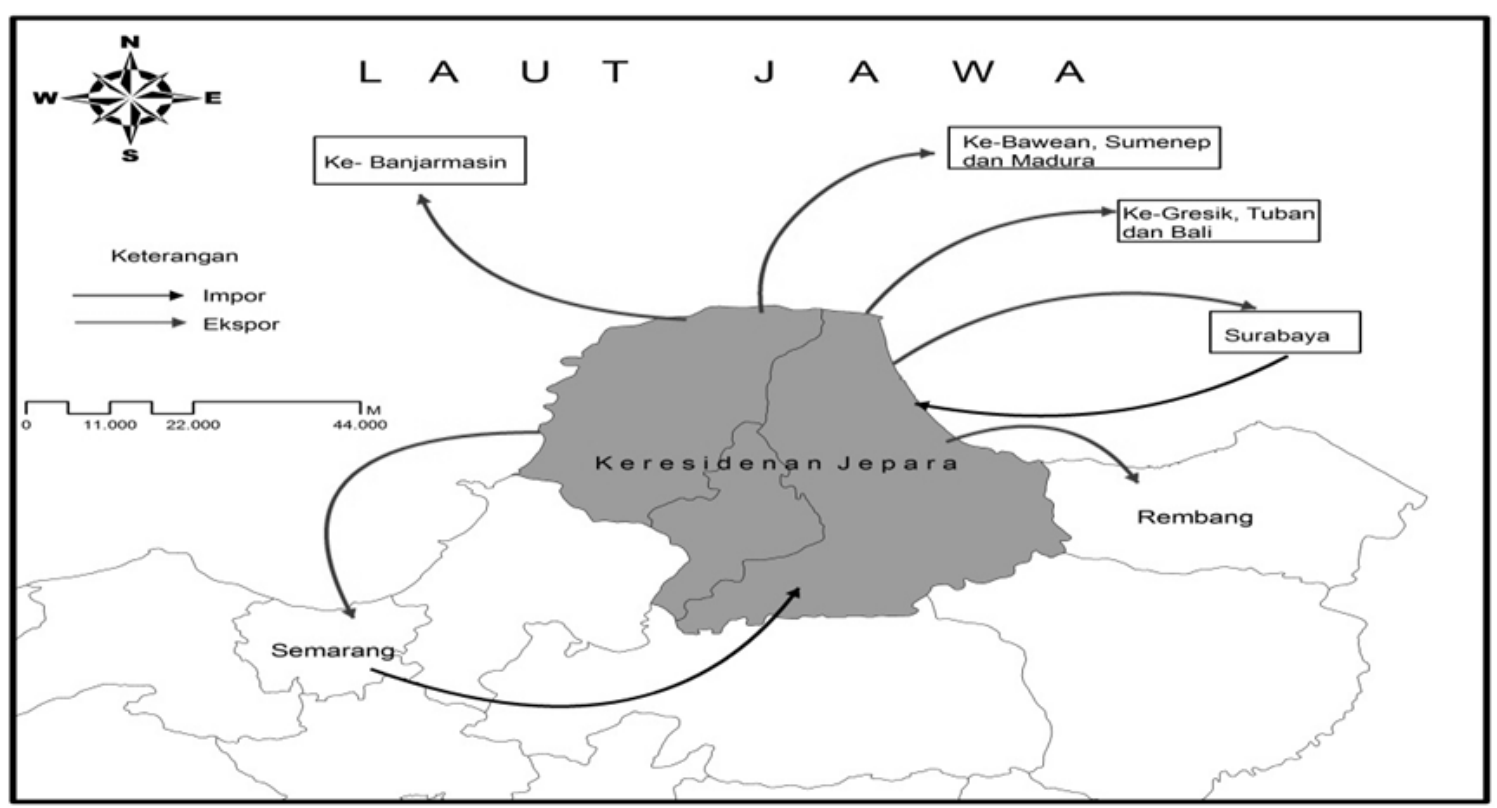

Gambar 1. Peta Persebaran Ekspor-Impor di Keresidenan Jepara (Sumber: Rekonstruksi ulang ini diolah dari berbagai sumber Peta 1858; Peta 1884, van Niel, 2003; A.V. 1843, bundel Jepara no. 4.1 ANRI- AV 1891 
akukan oleh pedagang lokal. Mereka membeli produk seperti ketela, ubi, dan komoditas lain dari penduduk dan mengirimkannya ke ibukota kabupaten dan keresidenan (A.V. 1887, bundel No. 7.II.M)

\section{Pedagang Eropa}

Selain aktivitas perdagangan dilakukan oleh pedagang Timur Asing, pedagang interinsuler, dan pedagang lokal juga dilakukan oleh pedagang Eropa. Di wilayah Keresidenan Jepara ini hanya terdapat beberapa pedagang Eropa (A.V. 1874, bundel No. 7.II.A). Para pedagang ini mengimpor komoditas utama seperti lilin, tembakau, lada, baja, beras, kulit kerbau dan kulit sapi, kain Eropa, rotan pengikat, gambir, minyak, kuda, sarang burung, kayu cat, dan sebagainya. Sementara itu komoditas ekspor yang dikelola oleh pedagang Eropa terdiri atas padi, kain katun, seng, sirup, kapuk, sarung Jawa, peti, perabotan, kacang, asam, kelapa, dan sebagainya (A.V. 1843).

Pada tahun 1852, penduduk Eropa yang tinggal di wilayah ini banyak yang membuka usaha perkebunan. Kesepakatan penduduk pada awalnya dilakukan tidak dengan sukarela. Hal ini mendasarkan pada Lembaran Negara 1838 nomor 50. Dalam perkembangannya, aturan tersebut dicabut karena memberatkan penduduk pribumi (A.V. 1857, bundel Jepara no. 5 II B).

Di keresidenan ini hanya ada beberapa kegiatan usaha yang sahamnya dimiliki oleh orang Eropa. Kebanyakan orang Eropa memiliki perkebunan di wilayah ini. Tetapi para pengusaha Eropa ini sebagian besar tinggal di Semarang dan di Belanda. Para pengusaha perkebunan mendapat keuntungan besar dengan menjual produk perkebunan seperti produk gula. Bila kegiatan usa- hanya gagal dan tidak memperoleh keuntungan, para pengusaha Eropa ini akan pindah ke tempat lain. Pada periode tahun 1850-an, para pengusaha gula dan tembakau mendapatkan keuntungan karena harga produk tersebut cukup tinggi (P.V. 1857).

Para pedagang Eropa tinggal di ibukota kabupaten. Mereka menjual barang dagangan yang dibutuhkan oleh penduduk Eropa dan para kepala pribumi. Mereka melayani penjualan minuman keras, makanan, kain, dan komoditi lain yang dibutuhkan setiap hari (A.V. 1850, bundel no. 4.II.a. ANRI).

Aktivitas perdagangan Eropa dilakukan oleh orang- orang Armenia. Sebagian besar mata pencaharian mereka terdiri atas usaha kecil-kecilan atau bekerja pada perusahaan perkebunan. Orang-orang Mestizo sebagian kecil bekerja pada perdagangan kecil, mengelola warung, atau melakukan perdagangan keliling, serta berdagang busana siap pakai (P.V. 1857).

Penduduk Eropa tidak banyak melakukan aktivitas perdagangan yang berkaitan dengan hasil bumi. Jumlah orang Eropa yang terlibat dalam perdagangan sangat kecil karena hampir sebagian besar orang Eropa di keresidenan ini adalah pegawai, pemilik atau pekerja di perusahaan perkebunan. Hanya sedikit yang menjadi pedagang (P.V. 1870, bundel No. 7.I.B; A.V. 1871, bundel No. 7.I.C).

\section{SIMPULAN}

Di tengah penetrasi ekonomi kolonial yang semakin intensif pada pertengahan abad ke-19, masyarakat Keresidenan Jepara masih mampu melakukan adaptasi terhadap perubahan ekonomi. Merosotnya peran pelabuhan Jepara sebagai pelabuhan perdagangan internasional dan interin- 
suler pada abad awal abad ke-19 mempengaruhi aktivitas ekonomi masyarakat. Ketergantungan masyarakat pada sektor agraris semakin besar. Namun demikian bukan berarti tradisi perdagangan masyarakat Keresidenan Jepara menjadi hilang. Aktivitas perdagangan masih tetap ada dengan mengandalkan perdagangan lokal, perdagangan interinsuler, dan perdagangan internasional yang terbatas.

Para pelaku perdagangan terdiri dari para pedagang lokal, pedagang Timur Asing (Cina, Arab. Moor), pedagang interinsuler (Makasar, Bugis, Bali, Borneo, Keling, Palembang, Sumatra dari pantai barat, Melayu dan Bengala), dan pedagang lokal. Para pedagang ini melakukan aktivitas perdagangan ekspor dan impor. Produk yang diekspor berasal dari daerah hinterland dan produk ikan.. Adapun produk yang diimpor berasal dari luar negeri. Kegiatan ekspor dan impor dilakukan melalui Semarang dan Surabaya. Adanya dinamika perdagangan ini adalah wajar karena di Keresidenan Jepara mempunyai daerah hinterland penghasil produk yang dibutuhkan oleh pasar dan mempunyai 9 (sembilan) industri gula pemerintah serta 8 (delapan) industri gula swasta. Berbekal pada potensi hinterland tersebut, maka tradisi dagang yang dimiliki oleh masyarakat Jepara pada masa lalu masih tetap eksis pada abad ke-19, utamanya pada tahun 1843 hingga 1891.

\section{DAFTAR PUSTAKA}

\section{Arsip dan Dokumen}

Algemeen Jaarlijksch Verslag Residentie Jepara, 1843. Jakarta: ANRI.

Algemeen Verslag Van De Residentie Japara Over Het Jaar 1850-1. Bundel No. 4.II.A. Jakarta: ANRI.

Algemeen Verslag Der Residentie Japara Over Het Jaar 1857. Bundel No. 5 II B. Jakar- ta: ANRI.

Algemeen Verslag Der Residentie Japara Over Het Jaar 1858. Bundel No. 5.II.C dan 5 II D. Jakarta: ANRI.

Algemeen Verslag Der De Residentie Japara Over Het Jaar 1859. Bundel 5. II. F. Jakarta: ANRI.

Algemeen Verslag Der Residentie Japara Over Het Dienstjaar 1860. Bundel No. 6.I.A. Jakarta: ANRI.

Algemeen Verslag Der Residentie Japara Over Het Jaar 1861. Bundel Jepara 6.I.C. Jakarta: ANRI.

Algemeen Verslag Der Residentie Japara Over Het Jaar 1862. Bundel No. 6.I. F. Jakarta: ANRI

Algemeen Verslag Der Residentie Jepara Over Het Jaar 1863. Bundel Jepara, No. 6.I.G. Jakarta: ANRI

Algemeen Verslag Der Residentie Jepara Over Het Jaar 1869. Bundel No. 6.II. K. Jakarta: ANRI.

Algemeen Verslag Der Residentie Japara Over Het Jaar 1870. Bundel No. 7.I.A. Jakarta: ANRI.

Algemeen Verslag Der Residentie Japara Over Het Jaar 1871. Bundel No. 7.I.C. Jakarta: ANRI.

Algemeen Verslag Van De Residentie Japara Over Het Jaar 1872. Bundel No. 7.1.E. Jakarta: ANRI.

Algemeene Verslag Der Residentie Japara Over Het Jaar 1873. Bundel No. 7.I.G. Jakarta: ANRI.

Algemeen Verslag Der Residentie Japara Over Het Jaar 1874. Bundel No. 7.II.A. Jakarta: ANRI.

Algemeen Verslag Der Residentie Japara Over Het Jaar 1875. Bundel No. 7.II.B. Jakarta: ANRI.

Algemeen Verslag Der Residentie Japara Over Het Jaar 1876. Bundel No. 7.II.C. Jakarta: ANRI.

Algemeen Verslag Der Residentie Japara Over Het Jaar 1877. Bundel No. 7.II.D. Jakarta: ANRI.

Algemeen Verslag Der Residentie Japara Over Het Jaar. 1878, bundel Jepara, No. 7.II.E

Algemeen Verslag Der Residentie Japara Over Het Jaar 1879. Bundel No. 7.II.F. Jakarta: ANRI.

Algemeen Verslag Der Residentie Japara Over Het Jaar 1880. Bundel No. 7.II.G. Jakarta: ANRI. 
Algemeen Verslag Der Residentie Japara Over Het Jaar 1881. Bundel No. 7.II.G. Jakarta: ANRI.

Algemeen Verslag Der Residentie Japara Over Het Jaar 1882. Bundel No. 7.II.H. Jakarta: ANRI.

Algemeen Verslag Der Residentie Japara Over 1887. Bundel No. 7.II.M. Jakarta: ANRI.

Algemeen Verslag Der Residentie Japara Over Het Jaar 1889. Bundel No. 7.II.O. Jakarta: ANRI.

Algemeen Verslag Der Residentie Japara Over 1891. Bundel No. 7.II.Q. Jakarta: ANRI.

Politiek Verslag Karesidenan Jepara (1858, 1860). Jakarta: ANRI.

Politiek Verslag Karesidenan Jepara 1863. Jakarta: ANRI.

Politiek Verslag Karesidenan Jepara (1870). Jakarta: ANRI.

\section{Buku}

Abdullah, Taufik. 1984. Ke Arah penulisan Sejarah Sosial Daerah. Jakarta: Direkorat Jarahnitra. Proyek IDSN.

Elson, R.E. 1994. Village Java under the Cultivation System 1830-1870. Sidney: Asian Studies Assosiation With Allen and Unwin.

Fasseur, C. 1975. Kultuurstelsel en Koloniale Baten de Nederlandse Exp loitatie van Java 1840-1860. Leiden: Universitaire Pers.

Fasseur, C.1977. "Organisatie en Sociaal Economische Betekenis van de Gouvernements Suikerkultuur in Enkele Residenties op Java Omstreek 1850", dalam Bidragen tot de Taal-, Land-en Volkenkunde. Deel 133. Leiden: KITLV
Furnival, J.S.. 2009. Hindia Belanda; Studi Tentang Ekonomi Majemuk. Jakarta: Freedom Institute.

Garraghan, Gilbert J. 1947. A Guide to Historical Method. New York: Fordham UniversiI.

Geertz, Clifford. 1983. Involusi Pertanian; Proses Perubahan Ekologi di Indonesia. Terjemahan S. Supomo. Jakarta: Bhatara Aksara Karya.

- - - - 1984. "Culture and Social Change: The Indonesian Case" dalam Man, New Series, Vol. 19, No. 4 (Dec., 1984), pp. 511-532.

Gottschalk, Louis. 1975. Mengerti Sejarah. Terjemahan Nugroho Notosusanto. Jakarta: Yayasan Penerbit Universitas Indonesia

de Graaf, H. J en Pigeaud, T.G. Th. 1976. Islamic States in Java 1500-1700. Amsterdam: The Hague: Martinus Nijhoff.

Herlina, Nina. 2008. Metode Sejarah. Bandung: Satya Historika.

Lekkerkerker, C. 1931. “Javaansche Geographies Namen als Spiegel van Omgevingen de denkwijze van het Volk I". dalam de Indische Gids.

Murphey, Rhoads. 1989.“On the Evolution of the Port City". Dalam Frank Broeze, ed. Brides of the Sea Port Cities of Asia from the $16^{\text {th }}-20^{\text {th }}$ Centuries. Kensington: New South Wales University Press.

van Niel, Robert.. 2003. Sistem Tanam Paksa di Jawa. Terjemahan Suyatno Kartodirjo. Jakarta:LP3ES.

van der Lith, P.A. 1896. Encyclopaedie van Nederlandsch Indië, tweede deel. 's Gravenhage, 1896, Martinus Nijhoff

Veth. P.J. 1882. Jawa: Geographisch, Ethnologisch, Historisch, derde deel.Haarlem: Erven F. Bohn. 